\title{
Fungsi Eksekutif pada Prasangka Pengguna Facebook terhadap Presiden RI
}

\author{
Nova Aprianti ${ }^{1}$, Itto Nesyia Nasution ${ }^{2}$, Nurul Aiyuda ${ }^{3}$ \\ Novaaprianti1983@gmai.com ${ }^{1}$ \\ Fakultas Psikologi Universitas Abdurrab ${ }^{123}$
}

\begin{abstract}
Abstrak
Penelitian ini bertujuan untuk mengetahui hubungan antara fungsi eksekutif terhadap prasangka pada pengguna facebook. Subjek penelitian ini berjumlah 125 subjek yang berusia 20 - 40 tahun di kota Pekanbaru (78 wanita; 47 laki-laki). Teknik pemilihan sampel menggunakan accidental sampling. Data dikumpulkan dengan menggunakan dua skala, yaitu skala fungsi eksekutif dan skala prasangka. Skala disebarkan secara online menggunakan google form. Analisis dalam penelitian ini menggunakan pearson product moment. Hasil analisis menunjukkan adanya hubungan negative antara fungsi eksekutif terhadap prasangka $(\mathrm{p}<0,05)$. Koefisien korelasi antara fungsi eksekutif dan prasangka adalah -0,301. Temuan ini menunjukkan semakin tinggi fungsi eksekutif maka semakin rendah prasangka, atau sebaliknya semakin rendah fungsi eksekutif maka semakin besar kemungkinan individu untuk berprasangka kepada presiden RI.
\end{abstract}

Kata Kunci : fungsi eksekutif, prasangka, facebook

\begin{abstract}
This study aims to determine the relationship between executive function and prejudice on Facebook users. The subjects of this study were 125 subjects aged 20-40 years in the city of Pekanbaru (78 women; 47 men). The sample selection technique uses accidental sampling. Data were collected using two scales, namely the executive function scale and the prejudice scale. The scale is distributed online using google form. The analysis in this study uses the Pearson product-moment. The analysis showed a negative relationship between executive function and prejudice $(\mathrm{p}<0.05)$. The correlation coefficient between executive function and prejudice is $-0,301$. This finding shows the higher the executive function, the lower the prejudice, or conversely the lower the executive function, the more likely the individual is to prejudice the president of Indonesia.
\end{abstract}

Keywords: executive function, prejudice, facebook

\section{PENDAHULUAN}

Perkembangan teknologi dewasa ini tidak dapat dihindari, semakin mudahnya masyarakat memperoleh telepon genggam dan semakin banyaknya perusahaan penyedia jaringan internet membuat pengguna internet di Indonesia semakin meningkat. Sejak tahun 2018 masyarakat Indonesia yang terhubung dengan internet bertambah dari 143, 26 jiwaa menjadi 171,17 juta orang di tahun 2019 (APJII [Asosiasi Penyedia Jasa Internet Indonesia], 2018a, 2018b, 2019). Peningkatan pengguna media sosial di Indonesia juga di lihat dari hasil riset We are osial Hootsuite yang dirilis Januari 2019, pengguna media sosial di Indonesia mencapai 150 juta atau sebesar 56\% dari total populasi. Jumlah tersebut naik 20\% dari survei sebelumnya. Sementara pengguna media sosial mobile (gadget) mencapai 130 juta atau sekitar $48 \%$ dari populasi (Hootsuite (we are social), 2019). Salah satu penggunaan jaringan internet adalah media sosial.

Media sosial dapat mempengaruhi sikap individu (Ali \& Zinna, 2018). Pesan-pesan 
yang tercantum di media sosial dapat membentuk cara individu memandang dunia dan orang lain (Bissell \& Parrott, 2013). Selain itu, telah dikemukakan bahwa media sosial adalah media komunikasi yang memiliki pengaruh paling kuat (Bissell \& Parrot, 2013). Hal ini dikarenakan situs jejaring sosial telah menjadi sumber hiburan, pendidikan dan berita. Melalui mode video, gambar, dan artikel yang dibagikan secara online, orang-orang mengumpulkan banyak informasi atau berita dari media sosial (Ali \& Zinna, 2018).

Melalui media sosial individu memposting hal-hal tertentu dan percaya pada posting tertentu yang mungkin konsisten dengan keyakinan mereka (Ali \& Zinna, 2018). Sifat media sosial yang selalu ada, memungkinkan pengguna di bombardir dengan pesan tentang karakteristik dan kelompok apa yang harus disetujui atau dijauhi, apa yang harus dipikirkan orang, dan bagaimana mereka harus bersikap terhadap orang lain (Ali \& Zinna, 2018).

Berkembangnya teknologi, media sosial telah menjadi kebutuhan bagi para pengguna, baik itu WhatsApp, Facebook, Snapchat atau Instagram. Di Indonesia, facebook merupakan sosial media dengan jumlah akun aktif tertinggi dan paling sering di kunjungi. (Hootsuite (we are social), 2019). Selain itu, Facebook menjadi sumber berita terbesar di dunia, 44\% orang dari 26 negara yang disurvei mengatakan bahwa penggunaan Facebook digunakan untuk memperoleh berita.

Berdasarkan berita-berita pada Facebook mengungkapkan isu-isu atau berita yang terkait dengan Presiden RI (Periode 2014-2019), tidak jarang disertai dengan sikap negatif atau prasangka dari pengguna media sosial berupa antipati yang disampaikan di laman komentar. Menurut Sampson (1999), prasangka didefinisikan sebagai sikap negatif terhadap orang lain karena kategori sosial atau kelompok mereka. Kemudian, salah satu bentuk dari perilaku prasangka menurut Duckitt (1992)) adalah antipati.

Individu yang memberikan komentar pada berita-berita berkaitan dengan presiden cenderung memiliki keyakinan negatif merupakan ciri dari Presiden RI (Periode 2014-2015). Keyakinan negatif ini pada dasarya merupakan ciri dari komponen kognitif dari prasangka, hal ini sejalan dengan apa yang disampaikan Walgito (2003), bahwa komponen kognitif dari prasangka adalah komponen yang berhubungan dengan keyakinan atau pendangan negatif terhadap objek prasangka.

Mengacu pada fenomena di atas, dalam sebuah penelitian, telah diketahui bahwa orang dewasa memang menunjukkan tingkat prasangka yang lebih tinggi (Stewart, von Hippel, \& Radvansky, 2009). Menurut Stewart, Hipper, dan Radvansky (2009), hal ini terjadi karena fungsi eksekutif menurun dengan bertambahnya usia, meskipun orang yang lebih tua termotivasi untuk mengendalikan ekspresi prasangka, mereka kurang mampu mengontrol hal tersebut. Meskipun demikian, tidak semua orang dewasa memiliki tingkat prasangka yang tinggi. Orang dewasa dengan tingkat fungsi eksekutif yang lebih baik lebih mampu mengendalikan respon dari prasangka dibandingkan orang dewasa dengan tingkat fungsi eksekutif yang lebih rendah (Krendl, Heatherton, \& Kensinger, 2009).

Fungsi eksekutif mengacu pada proses kognitif yang terlibat dalam perencanaan, pelaksanaan, dan pengendalian diri, ini termasuk kemampuan mengendalikan diri untuk tidak melakukan perilaku yang tidak pantas dan mengganti perilaku yang tidak pantas ke perilaku yang lebih tepat (Whitley \& Kite, 2016). Menurut Anderson, Jacobs, dan Anderson, (2011), adapun karakteristik masalah fungsi eksekutif termasuk ketidakmampuan untuk fokus atau mempertahankan atensi, impulsif, disinhibisi, masalah working memory, kesulitan memantau 
atau mengatur kinerja diri, ketidakmampuan untuk merencanakan tindakan yang tepat, disorganisasi, kemampuan nalar buruk, kesulitan menghasilkan dan atau mengimplementasikan strategi, serta kegagalan untuk belajar dari kesalahan (Anderson et al., 2011). Kemudian, disfungsi eksekutif juga dapat dikaitkan dengan perilaku maladaptif, masalah moral dan sosial (Anderson et al., 2011). Kite dan Whitley (2016) juga menjelaskan bahwa ketika fungsi eksekutif seseorang lemah, orang akan memiliki kecendrungan untuk menunjukkan sikap negatif atau prasangka.

Berdasarkan uraian di atas, dalam menggunakan media sosial seperti facebook orang dewasa diasumsi memiliki kemampuan fungsi eksekutif yang baik sehingga diharapkan dapat mengendalikan prasangka, namun demikian fenomena menunjukkan mereka memiliki kesulitan untuk mengontrol prasangka pada penggunaan facebook. Dengan demikian, peneliti ingin mengetahui apakah terdapat hubungan antara fungsi eksekutif dan prasangka pengguna facebook terhadap Presiden RI.

\section{METODE}

Penelitian ini menggunakan metode kuantitatif dengan pendekatan korelasional. Subjek penelitian dalam penelitian ini 125 subjek yang terdiri dari laki-laki dan perempuan dewasa awal berusia 20 sampai 40 tahun yang menggunakan facebook di Kota Pekanbaru. Teknik pemilihan sampel dalam penelitian ini menggunakan accidental sampling.

Alat ukur yang digunakan dalam penelitian ini menggunakan skala fungsi eksekutif dan skala prasangka dengan menggunakan metode model skala likert. Skala fungsi eksekutif dibuat sendiri oleh peneliti berdasarkan aspek-aspek teori fungsi eksekutif dari Geldhof, Little, dan Colombo (2010) untuk membuat skala fungsi eksekutif, yang yang terdiri dari attention, inhibition, long-term memory, dan working memory. Koefisien reliabilitas skala fungsi eksekutif yaitu sebesar 0,089 dengan jumlah aitem 27. Skala prasangka dibuat berdasarkan aspek-aspek menggunakan teori prasangka dari Baker (2002), yang menyatakan terdapat beberapa komponen dari prasangka, yang terdiri dari stereotip, perasaan negatif, dan diskriminasi. Koefisien reliabilitas skala prasangka yaitu sebesar 0,94 dengan jumlah aitem 29 pernyataan.

\section{HASIL}

Tabel 1. Deskripsi subjek penelitian

\begin{tabular}{cccccc}
\hline Usia & Frekuensi & $\%$ & Jenis Kelamin & frekuensi & $\%$ \\
\hline 20-30 Tahun & 78 & $62.4 \%$ & Perempuan & 56 & $44.8 \%$ \\
\hline 31-40 Tahun & 47 & $37.6 \%$ & Laki-laki & 69 & $55.2 \%$
\end{tabular}

Tabel 2. Gambaran Hipotetik variabel Fungsi Eksekutif

\begin{tabular}{ccccccccc}
\hline Variabel & \multicolumn{4}{c}{ Empirik } & \multicolumn{4}{c}{ Hipotetik } \\
\cline { 2 - 9 } & Maks & Min & Mean & SD & Maks & Min & Mean & SD \\
\hline Fungsi Eksekutif & 135 & 77 & 96,6 & 14,5 & 135 & 27 & 81 & 18 \\
\hline Prasangka & 141 & 80 & 83,7 & 25,5 & 145 & 29 & 87 & 19,3 \\
\hline
\end{tabular}


Berdasarkan tabel di atas, dapat diketahui jumlah skor rata-rata (mean: 96,7, SD: 14,0) empirik lebih besar dari pada jumlah skor rata-rata (mean : 81, SD : 18) hipotetik pada skala fungsi eksekutif $(96,6>81)$, hal ini menunjukkan bahwa kemampuan fungsi eksekutif pada subjek penelitian ini tinggi. Kemudian, pada skala prasangka, skor rata-rata (mean: 83,7, SD : $25,5)$ empirik lebih kecil dari pada jumlah skor rata-rata (mean: 87, SD : 19,3) hipotetik pada skala prasangka $(83,9<87)$, hal ini menunjukkan bahwa prasangka pada subjek penelitian ini rendah.

Tabel 3. Kategori variabel Penelitian

\begin{tabular}{ccccccc}
\hline \multirow{2}{*}{ Variabel } & \multicolumn{2}{c}{ Tinggi } & \multicolumn{2}{c}{ Sedang } & \multicolumn{2}{c}{ Rendah } \\
\cline { 2 - 7 } & Frekuensi & $\%$ & Frekuensi & $\%$ & frekuensi & $\%$ \\
\hline Fungsi Eksekutif & 48 & $38.4 \%$ & 77 & $61.6 \%$ & 0 & $0 \%$ \\
\hline Prasangka & 19 & $15.2 \%$ & 85 & $68 \%$ & 21 & $16.8 \%$ \\
\hline
\end{tabular}

Berdasarkan tabel 3, hasil perhitungan menunjukkan dari 125 sampel penelitian terdapat 77 orang $(61.6 \%)$ yang memiliki tingkat fungsi eksekutif sedang. Kemudian, 48 orang (38.4\%) memiliki kemampuan fungsi eksekutif pada tingkat tinggi. Hasil perhitungan menunjukkan dari 125 sampel penelitian terdapat 21 orang $(16.8 \%)$ yang memiliki tingkat prasangka rendah. Kemudian, 85 orang (68\%) memiliki prasangka pada tingkat sedang dan 19 orang (15.2\%) memiliki tingkat prasangka yang tinggi.

\section{Uji Asumsi}

Berdasarkan uji normalitas menggunakan Kolmogorov-Smirnov, diperoleh nilai signifikansi sebesar 0,074 ( $>0,05)$ untuk variabel fungsi eksekutif dan 0,215 ( $>0,05)$ untuk variabel prasangka. Berdasarkan nilai signifikansi dapat disimpulkan bahwa data variabel fungsi eksekutif dan prasangka berdistribusi normal. Kemudian, pada uji linearitas diperoleh bahwa $\mathrm{F}=14,016$ dan $p=0,000(<0,05)$. Signifikansi kurang dari 0,05, maka dapat disimpulkan bahwa antara variabel fungsi eksekutif dan prasangka terdapat hubungan yang linear.

\section{Uji Hipotesa}

Tabel 4. Uji Hipotesis

\begin{tabular}{lccc}
\hline \multicolumn{1}{c}{ Variabel } & Korelasi & Sig & Keterangan \\
\hline Fungsi eksekutif terhadap prasangka & $-0,301^{* *}$ & 0,001 & Signifikan \\
\hline Atensi terhadap prasangka & $-0,342^{* *}$ & 0,00 & Signifikan \\
\hline Inhibisi terhadap prasangka & $-0,254^{* *}$ & 0,04 & Signifikan \\
\hline LTM terhadap prasangka & $-0,107$ & 0,23 & Tidak Signifikan \\
\hline WM terhadap prasangka & $-0,287^{* *}$ & 0,00 & Signifikan \\
\hline Keterangan: LTM: Long term memory & WM: Working memory &
\end{tabular}

Berdasarkan tabel 4. di atas diketahui bahwa nilai signifikansi 0,001 ( $p<0,05)$, yang artinya terdapat hubungan signifikan antara fungsi eksekutif dengan prasangka. Kemudian, juga diketahui bahwa koefisien korelasi antara fungsi eksekutif dan prasangka -0,314, artinya arah hubungan fungsi eksekutif dan prasangka bersifat negatif. Semakin tinggi fungsi eksekutif 
maka semakin rendah tingkat prasangka. Dengan demikian, hipotesa dalam penelitian ini diterima

Melalui tabel 4. diketahui bahwa masing-masing komponen fungsi eksekutif memiliki korelasi dengan arah negatif terhadap prasangka. Korelasi antara atensi dan prasangka -0, 342, inhibisi dan prasangka $-0,254$,long term memory dan prasangka $-0,107$, terakhir working memory dan prasangka -0,287. Berdasarkan hasil tersebut dapat disimpulkan bahwa semakin tinggi masing-masing komponen dari fungsi eksekutif maka semakin rendah prasangka

\section{PEMBAHASAN}

Penelitian ini bertujuan untuk mengetahui hubungan antara fungsi eksekutif dengan prasangka pengguna facebook terhadap Presiden RI. Hasil dari penelitian ini menunjukkan bahwa fungsi eksekutif dan prasangka memiliki hubungan yang signifikan dengan arah hubungan negatif. Artinya, semakin tinggi kemampuan fungsi eksekutif maka semakin rendah prasangka pengguna facebook terhadap Presiden RI.

Mengacu pada hasil penelitian ini, dapat diketahui dan dipahami bahwa fungsi eksekutif menjadi faktor penting dalam mengendalikan prasangka seseorang yang menggunakan facebook. Hasil penelitian ini selaras dengan penelitian Ito dkk., (2017), telah diketahui bahwa motivasi untuk mengendalikan prasangka bergantung pada peran dari fungsi eksekutif.

Proses terjadinya prasangka pada dasarnya dapat dijelaskan menggunakan teori pengendalian diri seperti structural approach theory (based on cognitive neuroscience) yang dijelaskan oleh Geldhof dkk., (2010). Berdasarkan structural approach theory, pengendalian diri atau pengendalian perilaku seseorang sangat bergantung pada fungsi eksekutif seseorang, yang terdiri dari attention, inhibition, dan memory (long term memory dan working memory).

Mengacu pada structural approach theory (Geldhof et al., 2010), dapat disimpulkan bahwa semakin seseorang memiliki fungsi eksekutif yang tinggi, semakin mampu orang tersebut untuk mengendalikan dirinya untuk berperilaku dan bersikap di lingkungan sosial, termasuk media sosial seperti facebook. Sebaliknya, semakin seseorang memiliki fungsi eksekutif yang rendah, semakin sulit orang tersebut untuk mengontrol perilaku dan sikap di lingkungan sosial. Sehingga, hal ini pada akhirnya menyebabkan adanya fenomena dimana orang-orang memiliki disposisi atau kecendrungan untuk beperilaku dan bersikap negatif di media sosial seperti facebook.

Lebih rincinya, structural approach theory (Geldhof et al., 2010)menjelaskan terdapat beberapa aspek atau komponen utama yang menjadi fondasi dari terbentuknya fungsi eksekutif yang dapat memengaruhi pengendalian diri seseorang. Pertama adalah kemampuan atensi, kemampuan ini dianggap penting dalam pengendalian diri secara sadar. Jika seseorang tanpa kemampuan untuk mengarahkan atensi secara sadar, perilaku tidak akan dapat dikontrol secara sadar (Geldhof et al., 2010). Hasil dari penelitian ini menunjukkan bahwa adanya korelasi negatif antara atensi dan prasangka. Selaras dengan penelitian yang dilakukan oleh Payne (2005), telah diketahui bahwa adanya korelasi antara atensi dengan motivasi untuk mengendalikan prasangka. Kemudian, rendahnya kemampuan kontrol atensi juga berdampak terhadap stereotip dan perilaku diskriminasi (Payne, 2005). Menurut Baker (2002), stereotip dan perilaku diskriminasi merupakan salah satu komponen dari prasangka.

Kedua adalah inhibisi, merupakan kemampuan untuk berfikir sebelum berperilaku atau bersikap (Dawson \& Guare, 2006). Seorang pengguna media sosial yang memiliki inhibisi yang 
rendah, akan memiliki kecendrungan untuk berprasangka atau sulit untuk menahan keinginan untuk mengatakan atau melakukan sesuatu yang tidak sesuai dengan norma sosial. Hasil penelitian ini menunjukkan adanya korelasi negatif antara inhibisi dan prasangka. Selaras dengan penelitian (Krämer, Kopyciok, Richter, Rodriguez-Fornells, dan Münte (2011), telah diketahui bahwa lemahnya kemampuan inhibisi (disinhibisi) akan mempengaruhi perilaku agresif.Kemudian, menurut Kite dan Whitley (2016), perilaku agresif merupakan salah satu ciri dari perilaku diskriminasi, dan perilaku diskriminasi merupakan salah satu komponen dari prasangka (Baker, 2000).

Komponen yang kelima adalah memori, yang terdiri dari long term memory dan working memory. Long term memory memediasi peran atensi pada regulasi diri dengan mengarahkan atensi ke informasi yang sebelumnya relevan dalam situasi yang sama (Geldhof et al., 2010). Hasil penelitian ini menunjukkan adanya korelasi negatif antara long term memory dan working memory terhadap prasangka. Menurut Geldhof, Little, dan Colombo (2010), individu yang memiliki fungsi working memory yang baik akan mampu meregulari diri (Geldhof et al., 2010). Menurut Kennedy (2017), individu dengan kelemahan fungsi eksekutif bagian memori memiliki kecendrungan untuk membuat kesimpulan hanya berdasarkan informasi yang terbatas.

Selain structural approach theory, terjadinya prasangka juga dapat dijelaskan menggunakan information processing theory. Teori ini didasarkan pada gagasan bahwa manusia memproses informasi diterima, bukan hanya merepon informasi (Lindsay \& Donald A Norman, 1997). Perspektif dari teori ini menyamakan pikiran dengan komputer untuk menganalisis informasi dari lingkungan. Kemudian teori ini meyakini bahwa otak bekerja secara berurutan, seperti halnya komputer. Urutannya adalah menerima informasi (input), memproses informasi, dan memberi respon (output). Informasi ditangkap melalui sensori manusia, informasi tersebut kemudian diteruskan ke dalam memori (memori jangka pendek dan memori jangka panjang), dimana informasi tersebut direspon berdasarkan apa yang tersimpan di memori (Lindsay \& Donald A Norman, 1997). Keakuratan informasi yang diterima bergantung pada kemampuan atensi, dan cara seseorang merespon informasi bergantung pada kemampuan memori (Lindsay \& Donald A Norman, 1997). Information processing theory pada dasarnya selaras dengan penjelasan structural approach theory, yang menyatakan bahwa peran dari kemampuan atensi dan memori sangat penting dalam menentukan perilaku atau respon individu terhadap informasi yang diterima (Kennedy, 2017).

\section{KESIMPULAN}

Berdasarkan hasil penelitian dan pembahasan maka dapat disimpulkan bahwa kemampuan fungsi eksekutif memiliki peran penting dalam mengontrol prasangka individu dewasa awal dalam menggunakan Facebook. Semakin tinggi kemampuan fungsi eksekutif, maka semakin rendah prasangka seseorang. Sebaliknya, semakin rendah fungsi eksekutif maka semakin tinggi prasangka. Maka dari itu, untuk mengurangi prasangka pengguna facebook harus berpikir sebelum bertindak, dan selanjutnya mencari informasi lengkap sebelum menyimpulkan sesuatu. 


\section{DAFTAR PUSTAKA}

Ali, K. A., \& Zinna, A. A. (2018). Relationship between Prejudice, Social Media Addiction, Empathy and Trust. The International Journal of Indian Psychology, 6(3). https://doi.org/10.25215/0603.034

Anderson, V., Jacobs, R., \& Anderson, P. J. (2011). Executive functions and the frontal lobes: A lifespan perspective. Executive Functions and the Frontal Lobes: A Lifespan Perspective. https://doi.org/10.4324/9780203837863

APJII [Asosiasi Penyedia Jasa Internet Indonesia]. (2018a). Laporan Survei : Penetrasi \& Profil Perilaku Pengguna Internet Indonesia. APJII. Retrieved from www.apjii.or.id

APJII [Asosiasi Penyedia Jasa Internet Indonesia]. (2018b). Survei APJII: Penetrasi Internet di Indonesia Capai 143 Juta Jiwa. Buletin APJII, Edisi-22(Maret), 1-7.

APJII [Asosiasi Penyedia Jasa Internet Indonesia]. (2019). Laporan Survei : Penetrasi \& Profil Perilaku Pengguna Interneet Indonesia. Buletin APJII, Edisi 40(Mei), 1-6. Retrieved from https://apjii.or.id/survei

Baker, N. L. (2002). Prejudice. In J. Worell (Ed.), Encyclopedia of women and gender (pp. 865-877). USA: Academic Press.

Bissell, K., \& Parrott, S. (2013). Prejudice: the role of the media in the development of social bias. Journalism and Communication Monographs, 15(4), 219-270. https://doi.org/10.1177/1522637913504401

Dawson, P., \& Guare, R. (2006). Executive Skills in Children and Adolescents. Journal of Developmental \& Behavioral Pediatrics (2nd ed.). The Guilford Press. https://doi.org/10.1097/00004703-200606000-00014

Duckitt, J. (1992). Prejudice and behavior: A review. Current Psychology: Research \& Reviews, 11(4), 291-307. https://doi.org/10.1007/BF02686787

Geldhof, G. J., Little, T. D., \& Colombo, J. (2010). Self-regulation across the life span. In R. M. Lerner, M. E. Lamb, \& A. M. Freund (Eds.), The handbook of life-span development: Social and emotional development (pp. 116-157). USA: John Wiley \& Sons.

Hootsuite (we are social). (2019). Indonesia Digital Report 2019.

Ito, T. A., Friedman, N. P., Bartholow, B. D., Correll, J., Loersch, C., Altamirano, L. J., \& Miyake, A. (2017). Toward a Comprehensive Understanding of Executive Cognitive Function in Implicit Racial Bias. Journal of Personality and Social Psychology, 18(2), 187-218. https://doi.org/10.1016/j.physbeh.2017.03.040

JR, B. E. W., \& Kite, M. E. (2016). The Psychology of Prejudice and Discrimination (Second Thi). New York: Taylor \& Francis.

Kennedy, M. R. T. (2017). Coaching college students with executive function problems. The Guilford Press. New York: The Guilford Press.

Krämer, U. M., Kopyciok, R. P. J., Richter, S., Rodriguez-Fornells, A., \& Münte, T. F. (2011). The role of executive functions in the control of aggressive behavior. Frontiers in 
Psychology, 2(JUL), 1-10. https://doi.org/10.3389/fpsyg.2011.00152

Krendl, A. C., Heatherton, T. F., \& Kensinger, E. A. (2009). Aging Minds and Twisting Attitudes: An fMRI Investigation of Age Differences in Inhibiting Prejudice. Psychology and Aging, 24(3), 530-541. https://doi.org/10.1037/a0016065

Lindsay, P. H., \& Donald A Norman. (1997). Human Information Processing : An Introduction to Psychology (Second Edi). New York: Academic Press.

Payne, B. K. (2005). Conceptualizing Control in Social Cognition: How Executive Functioning Modulates the Expression of Automatic Stereotyping. Journal of Personality and Social Psychology, 89(4), 488 -503. https://doi.org/10.1037/0022-3514.89.4.488

Sampson, E. E. (1999). Dealing with Differences: An Introduction to the Social Psychology of Prejudice. New York: Harcourt Brace.

Stewart, B. D., von Hippel, W., \& Radvansky, G. A. (2009). Age, Race, and Implicit Prejudice. Psychological Science. https://doi.org/10.1111/j.1467-9280.2009.02274.x

Walgito, B. (2003). Psikologi Sosial. Yogyakarta: Penerbit ANDY. 